\title{
DEVELOPMENT OF HPLC STABILITY DEMONSTRATING METHODOLOGY FOR QUANTIFYING AZELNIDIPINE AND TELMISARTAN IN TABLETS AND BULK TYPES: VALIDATION FOLLOWING ICH DIRECTIVES
}

\section{KRISHNAPHANISRI PONNEKANTI ${ }^{*}$, K. SUNITHA ${ }^{1}$}

1Department of Pharmacy, GITAM Institute of Pharmacy, GITAM Deemed to be University, Visakhapatnam, India 530045 Email: krishnaphanisri@gmail.com

Received: 18 May 2021, Revised and Accepted: 26 Jun 2021

\section{ABSTRACT}

Objective: Azelnidipine (AZEL) and Telmisartan (TELM) combination is referred to the sufferers of hypertension. No analytical process has yet been mentioned for the TELM and AZEL combination analysis. We, therefore, have designed for its first time stability demonstrating methodology based on HPLC for analysing TELM and AZEL in the tablets and bulk.

Methods: The assay of TELM and AZEL was get done on a $250 \mathrm{~mm}$ length C18 column (Supelco, $4.6 \mathrm{~mm}$ inner diameter, $5.0 \mu \mathrm{m}$ particle size), and utilized $0.1 \mathrm{M} \mathrm{Na}_{2} \mathrm{SO}_{4}(\mathrm{pH} 3.6$ ) and acetonitrile (55\% volume: $45 \%$ volume) as the mobile solvents phase, at a stream rate $1.0 \mathrm{ml} / \mathrm{min}$. HPLC recognition of TELM and AZEL was taken by a photodiode array sensor set at $258 \mathrm{~nm}$. For validation of the stability demonstrating methodology proposed in terms of sensitivity, precision, specificity, linearity, device adequacy, robustness and accuracy, ICH directives were followed.

Results: Calibration curves of TELM and AZEL were generated in the array of 20-60 $\mu \mathrm{g} / \mathrm{ml}$ and $4-12 \mu \mathrm{g} / \mathrm{ml}$ with recovery percentage ranges of 99.62\%-101.05\% and 97.76\%-100.17\%, and detection limits of $0.020 \mu \mathrm{g} / \mathrm{ml}$ and $0.009 \mu \mathrm{g} / \mathrm{ml}$, respectively. TELM and AZEL stability was inspected in the existence of acid, base, light, heat, and oxidation and it was realised to be more stable under oxidation degradation testing conditions employed when compared to acid, alkaline, photo, and heat degradation testing conditions applied.

Conclusion: The observations demonstrated that the described HPLC stability demonstrating methodology was suitable for quantitating TELM and AZEL combination in tablets and bulk.

Keywords: Azelnidipine, Telmisartan, Hypertension, Stability demonstrating, Analysis

(C) 2021 The Authors. Published by Innovare Academic Sciences Pvt Ltd. This is an open access article under the CC BY license (https://creativecommons.org/licenses/by/4.0/) DOI: https://dx.doi.org/10.22159/ijap.2021v13i5.42099. Journal homepage: https://innovareacademics.in/journals/index.php/ijap

\section{INTRODUCTION}

Hypertension is the extremely avoidable contributing factor for cardiovascular impairments namely coronary cardiac disease, heart attack, heart stroke, atrial fibrillation, pulmonary artery disease and myocardial infarction, progressive renal disease and cognitive decline [1]. Hypertension is the foremost single contributor to the world's leading basis of demise and disability. In 2010 it is valued that 1.39 billion (31.1\%) of adults globally be ill with hypertension. In middle and small revenue nations ( 1.04 billion people and $31.5 \%)$, the occurrence of hypertension among adults was elevated than in the high revenue nations (349 million individuals and 28.5\%) [2].

Azelnidipine (AZEL), structure in fig. 1, is a modern dihydropyridine calcium passage antagonist that is particular for the L-kind calcium passages and has received FDA authorization for therapy of the hypertension clients [3]. Antihypertensive outcomes of AZEL are equivalent to that of amlodipine [4]. AZEL is indeed increasingly lipid-soluble and has greater selectivity for the vascular surface than older generational calcium passage antagonists, and in animal experiments treated with AZEL, blood flowing to the brain was markedly enhanced [5].

Telmisartan (TELM), structure in fig. 1, is an angiotensin (II) receptor blockade being used to alleviate minimal to severe hypertension [6-8]. TELM is extremely selective for the type 1 angiotensin (II) receptors. TELM is an extra lipophilic angiotensin (II) receptor blocker than utmost other angiotensin (II) receptor inhibitors, which aids its oral uptake and tissue as well as cell permeation [9]. TELM too has an impact on the peroxisome proliferator triggered receptors, which are nuclear hormone receptor superfamily ligand triggered transcription elements. TELM, a drug that treats both diabetes and hypertension, may well be an alternative therapy choice $[10,11]$.

The combination of TELM and AZEL is recommended for hypertension sufferers. In hypertension sufferers, TELM and AZEL combination drops blood pressure, enables blood to flow more effectively to numerous tissues, allows the heart to operate more effectively, and increases oxygen flow across the body, and thereby reducing heart-associated chest pain [12].<smiles>CC1=C(C(=O)OC(C)C)C(c2cccc([N+](=O)[O-])c2)C(C(=O)OC2CN(C(c3ccccc3)c3ccccc3)C2)=C(N)N1</smiles><smiles>CCCC1Nc2c(C)cc(-c3nc4ccccc4n3C)cc2N1Cc1ccc(-c2ccccc2C(=O)O)cc1</smiles>

Telmisartan

Fig. 1: Azelnidipine (AZEL) and Telmisartan (TELM) structures

Stress tests must be implemented on a medication compound to ascertain its basic stability properties, bestowing to the "ICH Q1A (R2)" parent drug permanency evaluation recommendations [13]. Understanding how a drug substance's consistency varies with times and the nature of deterioration products generated under different 
storage circumstances affects the potency and wellbeing of pharmaceuticals is critical [14-16]. Stability demonstrating methods are a group of analytical methodologies that demonstrate the sample stability and must be completely validated. No Stability demonstrating method has yet been recommended for the TELM and AZEL combination. We developed, for the initial time, stability demonstrating methodology for TELM and AZEL combination in tablets and bulk in this report. The approach developed is indeed dependent on reverse-phase liquid chromatography with a photodiode sensor, that has been configured for the investigation of the TELM and AZEL combination in a fast, precise, and sensitive manner.

\section{MATERIALS AND METHODS}

\section{Instrumentation and analysing conditions of TELM and AZEL combination}

High-performance liquid chromatography (Waters 2695 model HPLC system, Autosampler) accompanying with photodiode detector (2998 model) was used in the procedure development and combination analysis of TELM and AZEL. The very fine particles loaded $25 \mathrm{fmm}$ length C18 column (Supelco, 4.6mm inner diameter, $5.0 \mu \mathrm{m}$ particle size) was utilised for TELM and AZEL chromatographic separation. Flow of $1 \mathrm{ml} / \mathrm{min}$, utilised for the TELM and AZEL chromatographic separation. The mobile phase components of $0.1 \mathrm{M} \mathrm{Na} 2 \mathrm{SO} 4 \mathrm{(pH} 3.6)$ and acetonitrile (55\% volume: $45 \%$ volume) was used. The complete process was completed at room temperature. To every sample, the specimen $(10 \mu \mathrm{l})$ was chosen as the injection quantity. The quantitation of TELM and AZEL was done at $258 \mathrm{~nm}$.

\section{Chemicals}

"SD Fine chem Ltd (India)" supplied analytical mark $\mathrm{Na}_{2} \mathrm{SO}_{4}$, peroxide and $\mathrm{NaOH}$; "Merck (India)" supplied analytical mark $\mathrm{HCl}, \mathrm{H}_{3} \mathrm{PO}_{4}$ and HPLC mark acetonitrile; Milli Q System base prepared Milli Q water was employed in the combined analysis of TELM and AZEL.

\section{Reference drugs and tablets}

"Rainbow pharma training laboratories (India)" provided TELM and AZEL reference bulk samples. TELMA-AZ tablet type (Glenmark Pharmaceutical Ltd, India) was bought from a local shop drug retailer and claimed to comprise $8 \mathrm{mg}$ of AZEL and $40 \mathrm{mg}$ of TELM.

\section{TELM and AZEL combination solutions}

A stock TELM and AZEL combination solution (concentration: 400 $\mu \mathrm{g} / \mathrm{ml}$ TELM and $80 \mu \mathrm{g} / \mathrm{ml} \mathrm{AZEL)}$ was made by solubilizing $40 \mathrm{mg}$ of TELM and $8 \mathrm{mg}$ of AZEL in $25 \mathrm{ml}$ of mobile phase and then diluting to $100 \mathrm{ml}$ volume with the very similar solvent. A working TELM and AZEL combination solution (concentration: $40 \mu \mathrm{g} / \mathrm{ml}$ TELM and 8 $\mu \mathrm{g} / \mathrm{ml}$ AZEL) was made by solubilizing $1 \mathrm{ml}$ of stock TELM and AZEL combination solution in $3 \mathrm{ml}$ of mobile phase and then diluting to 10 $\mathrm{ml}$ volume with the very similar solvent.

\section{Procedure for evaluating the TELMand AZEL combination in bulk}

Different aliquots covering $20 \mu \mathrm{g} / \mathrm{ml}-60 \mu \mathrm{g} / \mathrm{ml}$ of TELM and 4.0 $\mu \mathrm{g} / \mathrm{ml}-12.0 \mu \mathrm{g} / \mathrm{ml}$ of AZEL were correctly shifted from stock TELM and AZEL combination solution (concentration: $400 \mu \mathrm{g} / \mathrm{ml}$ TELM and $80 \mu \mathrm{g} / \mathrm{ml} \mathrm{AZEL}$ ) into separate sets of $10 \mathrm{ml}$ volumetric flasks, and then diluting to $10 \mathrm{ml}$ volume with the very similar solvent. 10 $\mu \mathrm{l}$ volume of each solution were infused into $250 \mathrm{~mm}$ length C18 column (Supelco, $4.6 \mathrm{~mm}$ inner diameter, $5.0 \mu \mathrm{m}$ particle size) and evaluated with "stability-indicating HPLC methodology" conditions given (see section: Instrumentation and analysing conditions of TELM and AZEL combination). The peak response values of TELM and AZEL at $258 \mathrm{~nm}$ were recorded and afterward calibration curves of TELM and AZEL were drawn followed by calculating regression equations of TELM and AZEL. The concentration of TELM and AZEL in nameless specimen solution can be assessed by exploiting the calibration curves of TELM and AZEL or regression equations of TELM and AZEL, respectively.

Procedure for evaluating the TELMand AZEL combination in tablets

A total of 20 tablets (TELMA-AZ tablet, claimed to comprise $8 \mathrm{mg}$ of AZEL and $40 \mathrm{mg}$ of TELM) were collected, with the median weight estimated and mashed to a fine powder. Dose comparable to $40 \mathrm{mg}$ of TELM and $8 \mathrm{mg}$ of AZEL was shifted to a volumetric flask (100 $\mathrm{ml}$ ), blended with $10 \mathrm{ml}$ of mobile and stirred with ultra sonicator at $27^{\circ} \mathrm{C}$ for $20 \mathrm{~min}$, diluted with similar solvent up to $100 \mathrm{ml}$ mark and filtered via a filter membrane $(0.45 \mathrm{~m})$. This tablet stock solution has $400 \mu \mathrm{g} / \mathrm{ml} \mathrm{TELM} \mathrm{and} 80 \mu \mathrm{g} / \mathrm{ml}$ AZEL. A sample tablet TELM and AZEL combination solution (threotical concentration: $40 \mu \mathrm{g} / \mathrm{ml}$ TELM and $8 \mu \mathrm{g} / \mathrm{ml}$ AZEL) for the analysis was made by solubilizing 1 $\mathrm{ml}$ of tablet stock TELM and AZEL combination solution in $3 \mathrm{ml}$ of mobile phase and then diluting to $10 \mathrm{ml}$ volume with the very similar solvent. $10 \mu \mathrm{l}$ volume of sample tablet TELM and AZEL combination solution were infused into $250 \mathrm{~mm}$ length C18 column (Supelco, $4.6 \mathrm{~mm}$ inner diameter, $5.0 \mu \mathrm{m}$ particle size) and evaluated with "stability-indicating HPLC methodology" conditions specified (see section: Instrumentation and analysing conditions of TELM and AZEL combination). At $258 \mathrm{~nm}$, the peak response values of TELM and AZEL were measured. The amount of TELM and AZEL in the tablet specimen solution can be established by employing TELM and AZEL calibration curves or regression equations, respectively.

\section{Stability testing of TELM and AZEL}

The stability of TELM and AZEL should be assessed by a stress testing stability analysis. This research illustrates the stability of TELM and AZEL in the presence of acid, base, light, heat, and oxidation [13].

\section{Acid degradation testing}

The investigation was done out using $0.1 \mathrm{~N}$ hydrochloric acid $(10$ $\mathrm{ml})$. The TELM and AZEL stock tablet solution $(400 \mu \mathrm{g} / \mathrm{ml}$ TELM and $80 \mu \mathrm{g} / \mathrm{ml}$ AZEL) was combined in an equivalent volume proportion with acid and blended into the volumetric flask $(100 \mathrm{ml})$. The blend was stirred for $30 \mathrm{~min}$ at $27^{\circ} \mathrm{C}$ using a ultra sonicator. The sample was mixed with mobile phase up to $100 \mathrm{ml}$ mark and filtered via a filter membrane $(0.45 \mathrm{~m})$ before being inserted $(10 \mu \mathrm{l})$ into the HPLC instrument for TELM and AZEL analysis with "stabilityindicating HPLC methodology" conditions specified (see section: Instrumentation and analysing conditions of TELM and AZEL combination).

\section{Oxidation degradation testing}

The oxidation degradation testing of TELM and AZEL was worked out with peroxide $(30 \%, 10 \mathrm{ml})$ as the oxidising agent. In a similar quantity volume, the stock TELM and AZEL tablet solution (400 $\mu \mathrm{g} / \mathrm{ml}$ TELM and $80 \mu \mathrm{g} / \mathrm{ml} \mathrm{AZEL}$ ) is blended with peroxide. The sample was stirred with ultra sonicator at $27^{\circ} \mathrm{C}$ for $30 \mathrm{~min}$, diluted with mobile phase up to $100 \mathrm{ml}$ mark and filtered via a filter membrane $(0.45 \mathrm{~m})$. The sample $(10 \mu \mathrm{l})$ was inserted into HPLC machine and the TELM and AZEL content were established with "stability-indicating HPLC methodology" conditions specified (see section: Instrumentation and analysing conditions of TELM and AZEL combination).

\section{Alkaline degradation testing}

The investigation was done out using $0.1 \mathrm{~N}$ sodium hydroxide $(10 \mathrm{ml})$. The tablet TELM and AZEL stock solution $(400 \mu \mathrm{g} / \mathrm{ml}$ TELM and 80 $\mu \mathrm{g} / \mathrm{ml}$ AZEL) was combined in an equivalent volume proportion with alkaline and blended into the volumetric flask $(100 \mathrm{ml})$. The blend was stirred for $30 \mathrm{~min}$ at $27^{\circ} \mathrm{C}$ using a ultra sonicator. The sample was mixed with mobile phase up to $100 \mathrm{ml}$ mark and filtered via a filter membrane $(0.45 \mathrm{~m})$ before being inserted into the HPLC instrument for TELM and AZEL analysis with "stability-indicating HPLC methodology" conditions specified (see section: Instrumentation and analysing conditions of TELM and AZEL combination).

\section{Photodegradation testing}

For this investigation, the stock solution of TELM $(400 \mu \mathrm{g} / \mathrm{ml})$ and AZEL $(80 \mu \mathrm{g} / \mathrm{ml})$ was placed into the volumetric flask $(100 \mathrm{ml})$ and exposed with sunlight for $6 \mathrm{~h}$. After that, the sample was mixed with mobile phase up to $100 \mathrm{ml}$ mark, filtered via a filter membrane $(0.45$ $\mathrm{m})$ and analysed for TELM and AZEL content using "stabilityindicating HPLC methodology" conditions specified (see section: Instrumentation and analysing conditions of TELM and AZEL combination). 


\section{Heat degradation testing}

For this report, the stock solution of TELM $(400 \mu \mathrm{g} / \mathrm{ml})$ and AZEL (80 $\mu \mathrm{g} / \mathrm{ml}$ ) was placed into the volumetric flask $(100 \mathrm{ml})$ and exposed with $60{ }^{\circ} \mathrm{C}$ for $30 \mathrm{~h}$ using an oven. After that, the sample was mixed with mobile phase up to $100 \mathrm{ml}$ mark, filtered via a filter membrane $(0.45 \mathrm{~m})$ and analysed TELM and AZEL content using "stability-indicating HPLC methodology" conditions specified (see section: Instrumentation and analysing conditions of TELM and AZEL combination).

\section{RESULTS}

Optimizing the analysing conditions of TELM and AZEL combination

With a "Supelco C18 column ( $5 \mu \mathrm{m} ; 4.6 \times 250 \mathrm{~mm}$ )" with a column slit temperature having $25^{\circ} \mathrm{C}$ and $0.1 \mathrm{M} \mathrm{Na} 2 \mathrm{SO}$-acetonitrile $(\mathrm{pH} 3.6$ and ratio $55: 45, \mathrm{v} / \mathrm{v}$ ) as mobile solvents phase and an isocratic stream form run of $1.0 \mathrm{ml} / \mathrm{min}$, optimal response, good system fittingness values (table 1) and proportioned peak nature for TELM and AZEL were obtained. The best match for the finest peak response and to quantify TELM and AZEL was recognized to be UV identification with a $258 \mathrm{~nm}$ configuration. Chromatographic analysis run phase for the TELM and AZEL evaluation was 7.0 min with retaining times of 2.757 and 3.664 min perceived for TELM and AZEL, respectively (fig. 2).

\section{Validation}

The HPLC-based stability demonstrating approach for TELM and AZEL was validated bestowing to the "ICH Q2 (R1)" recommendations $[17,18]$.

\section{Selectivity}

The specificity of TELM and AZEL analysing method was witnessed by analysing diluent $\left(0.1 \mathrm{M} \mathrm{Na}_{2} \mathrm{SO}_{4}\right.$-acetonitrile, $\mathrm{pH} 3.6$ and ratio $55: 45, \mathrm{v} / \mathrm{v})$, standard TELM and AZEL solution $(40 \mu \mathrm{g} / \mathrm{ml} \mathrm{TELM} \mathrm{and}$ $8 \mu \mathrm{g} / \mathrm{ml} \mathrm{AZEL})$ and formulation solution $(40 \mu \mathrm{g} / \mathrm{ml}$ TELM and 8 $\mu \mathrm{g} / \mathrm{ml}$ AZEL). The specificity chromatograms of TELM and AZEL are presented in fig. 3.

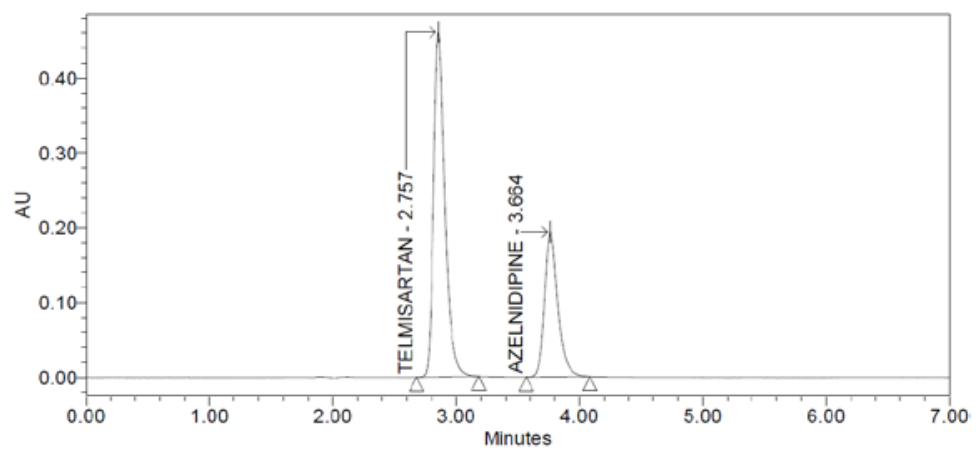

Fig. 2: TELM and AZEL chromatogram

Table 1: TELM and AZEL system appropriateness measures

\begin{tabular}{|c|c|c|c|c|c|c|}
\hline \multirow[t]{2}{*}{ Parameter } & \multicolumn{3}{|l|}{ TELM } & \multicolumn{3}{|l|}{ AZEL } \\
\hline & Mean value* & SD value & RSD value & Mean value* & SD value & RSD value \\
\hline Retention time & 2.754 & 0.002 & 0.077 & 3.666 & 0.004 & 0.116 \\
\hline Resolution & - & - & - & 4.974 & 0.011 & 0.229 \\
\hline Tailing & 1.372 & 0.004 & 0.326 & 1.308 & 0.004 & 0.342 \\
\hline Plate count & 5074 & 58.034 & 1.144 & 6109 & 40.054 & 0.656 \\
\hline Peak response & 2838577 & 9979.936 & 0.352 & 1570555 & 5471.114 & 0.348 \\
\hline
\end{tabular}

"mean of five measures; SD value-standard deviation value for five measures; RSD values-percentile standard deviation value for five measures
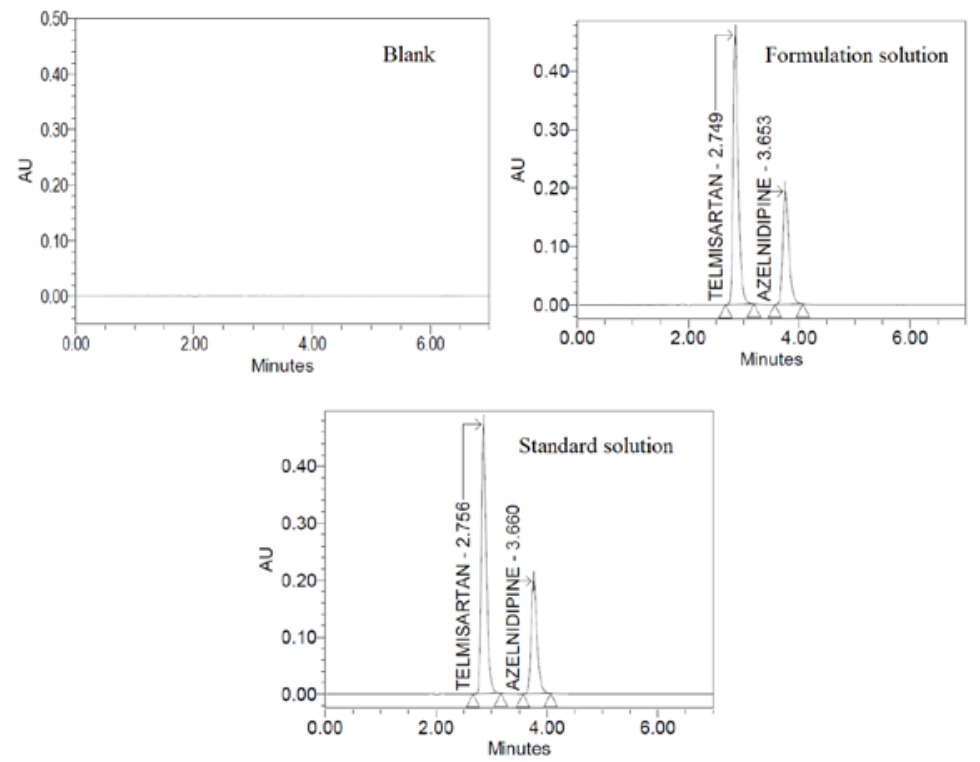

Fig. 3: TELM and AZEL specificity chromatograms 


\section{Linearity}

By analysing six solutions in the $20-60 \mu \mathrm{g} / \mathrm{ml}$ (TELM) and 4-12 $\mu \mathrm{g} / \mathrm{ml}$ (AZEL) concentration limits, we generated a calibration chart to illustrate linearity (fig. 4). The correlation coefficient, intercept and slope for TELM and AZEL calibration charts were recorded utilizing linear regression evidence analysis.
TELM regression equation: $\mathrm{y}=73577.83 x-124711.8$

TELM correlation coefficient: 0.9996

AZEL regression equation: $\mathrm{y}=190619.35 \mathrm{x}+14475.2$

AZEL correlation coefficient: 0.9980
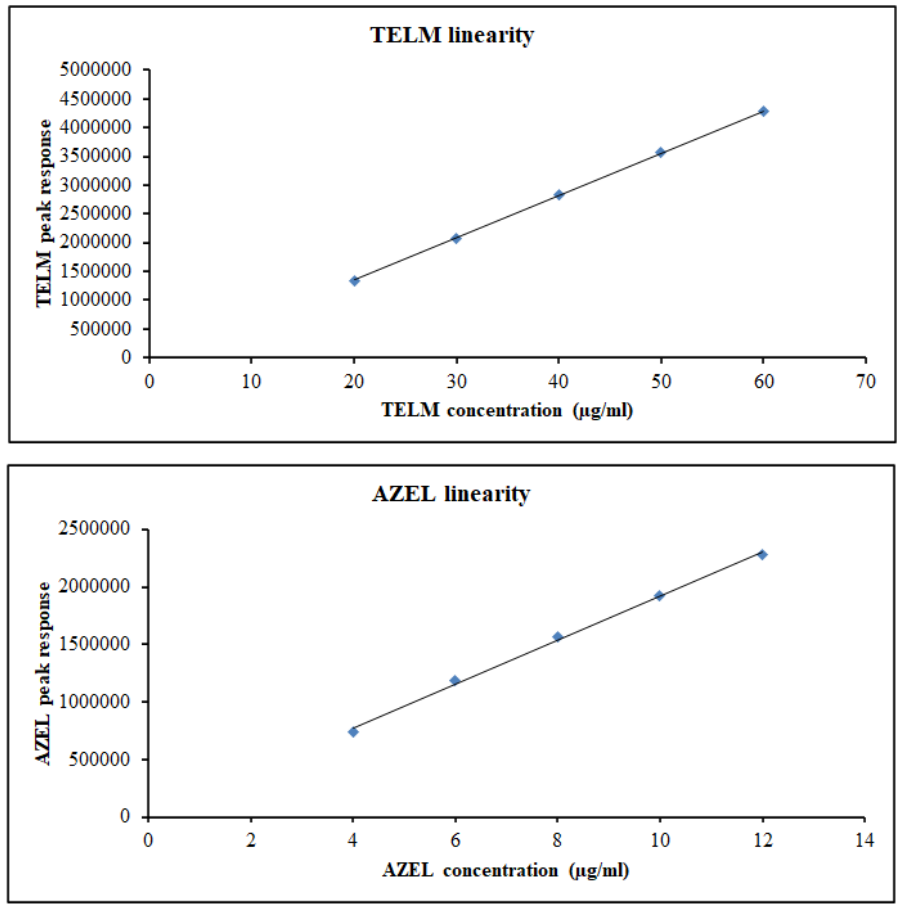

Fig. 4: Calibration charts of TELM and AZEL
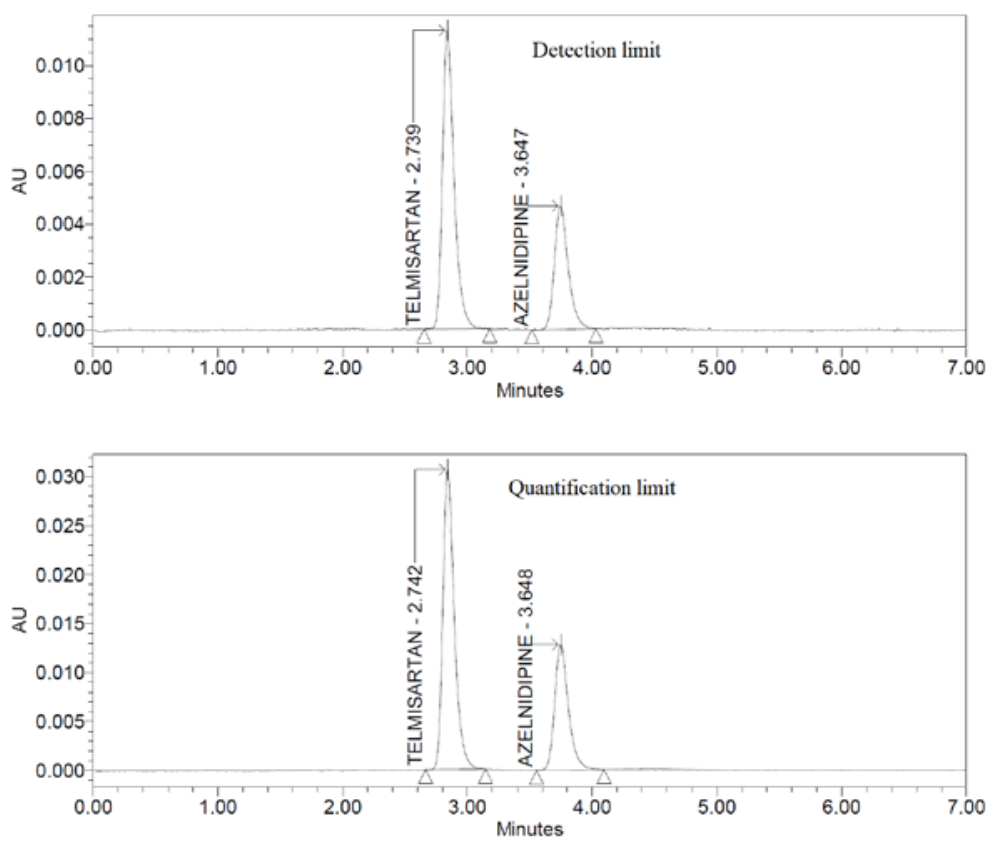

Fig. 5: TELM and AZEL chromatograms at their quantification and detection limits concentration

\section{Quantification and detection limits for TELM and AZEL}

The detection limits were characterized as the amount $(\mu \mathrm{g} / \mathrm{ml})$ of TELM and AZEL that should have being sensed and will yield signal/noise proportion of 3:1. The calculated detection limits for TELM and AZEL were $0.020 \mu \mathrm{g} / \mathrm{ml}$ and $0.009 \mu \mathrm{g} / \mathrm{ml}$, respectively. The quantitation limits were characterized as the amount $(\mu \mathrm{g} / \mathrm{ml})$ of TELM and AZEL that should have being sensed and will yield 
signal/noise proportion of 10:1. The calculated quantification limits for TELM and AZEL were $0.065 \mu \mathrm{g} / \mathrm{ml}$ and $0.031 \mu \mathrm{g} / \mathrm{ml}$, respectively. The TELM and AZEL chromatograms at their quantification and detection limit concentrations were represented in fig. 5 .

\section{Precision and accuracy}

These two criteria for HPLC based stability demonstrating approach was weighed up by the analysis of standard TELM and AZEL solution ( $40 \mu \mathrm{g} / \mathrm{ml}$ TELM and $8 \mu \mathrm{g} / \mathrm{ml}$ AZEL) by six repeated evaluation of two pure samples of TELM and AZEL on one day, the calculations resulted were exemplified in table 2 .

\section{Recovery}

This criterion for the HPLC-based stability demonstrating approach was weighed up employing the standard adding methodology. The formulation solutions $(40 \mu \mathrm{g} / \mathrm{ml}$ TELM and 8 $\mu \mathrm{g} / \mathrm{ml} \mathrm{AZEL)}$ were prepared and spiked at quantities comprising $19.8 \mu \mathrm{g} / \mathrm{ml}$ TELM and $3.96 \mu \mathrm{g} / \mathrm{ml}$ AZEL $(50 \%$ standard adding level), $39.6 \mu \mathrm{g} / \mathrm{ml}$ TELM and $7.92 \mu \mathrm{g} / \mathrm{ml}$ AZEL $(100 \%$ standard adding level) and $59.4 \mu \mathrm{g} / \mathrm{ml}$ TELM and $11.88 \mu \mathrm{g} / \mathrm{ml} \mathrm{AZEL}(150 \%$ standard adding level). These formulation solutions were assessed by three repeated evaluations, the calculations resulted were exemplified in table 3.

Table 2: TELM and AZEL measures for precision and accuracy

\begin{tabular}{lllll}
\hline Sample Inj* No. & Precision & Accuracy & \\
\cline { 2 - 5 } & TELM peak response & AZEL peak response & TELM \% assay & AZEL \% assay \\
\hline 1 & 2821726 & 1561001 & 98.71 & 99.09 \\
2 & 2824535 & 1558797 & 98.81 & 98.95 \\
3 & 2825550 & 1557448 & 98.84 & 98.87 \\
4 & 2818158 & 1565516 & 98.59 & 99.38 \\
5 & 2819465 & 1560065 & 98.63 & 99.03 \\
6 & 2825565 & 1562141 & 98.84 & 99.17 \\
Mean value & 2822500 & 1560828 & 98.74 & 99.08 \\
SD value & 3209.399 & 2823.571 & 0.112 & 0.179 \\
RSD value & 0.114 & 0.181 & 0.114 & 0.181 \\
\hline
\end{tabular}

"mean of six measures; SD value-standard deviation value for six measures; RSD values-percentile standard deviation value for six measures; Sample Inj* No.-Sample injection number

Table 3: TELM and AZEL recovery measures

\begin{tabular}{|c|c|c|c|c|c|}
\hline Spiked percent & Value spiked $(\mu \mathrm{g} / \mathrm{ml})$ & Value recovered (\%) & Mean value (\%) & SD value & RSD value \\
\hline \multicolumn{6}{|l|}{ TELM recovery } \\
\hline \multirow[t]{3}{*}{50} & 19.800 & 100.23 & 100.37 & 0.428 & 0.426 \\
\hline & 19.800 & 100.85 & & & \\
\hline & 19.800 & 100.03 & & & \\
\hline \multirow[t]{3}{*}{100} & 39.600 & 99.44 & 99.62 & 0.159 & 0.160 \\
\hline & 39.600 & 99.75 & & & \\
\hline & 39.600 & 99.66 & & & \\
\hline \multirow[t]{3}{*}{150} & 59.400 & 100.92 & 101.05 & 0.168 & 0.166 \\
\hline & 59.400 & 101.24 & & & \\
\hline & 59.400 & 100.99 & & & \\
\hline \multicolumn{6}{|l|}{ AZEL recovery } \\
\hline \multirow[t]{3}{*}{50} & 3.960 & 99.42 & 99.41 & 0.036 & 0.036 \\
\hline & 3.960 & 99.37 & & & \\
\hline & 3.960 & 99.44 & & & \\
\hline \multirow[t]{3}{*}{100} & 7.920 & 100.00 & 100.17 & 0.150 & 0.150 \\
\hline & 7.920 & 100.25 & & & \\
\hline & 7.920 & 100.27 & & & \\
\hline \multirow[t]{3}{*}{150} & 11.880 & 97.51 & 97.76 & 0.240 & 0.246 \\
\hline & 11.880 & 97.77 & & & \\
\hline & 11.880 & 97.99 & & & \\
\hline
\end{tabular}

"mean of three measures; SD value-standard deviation value for three measures; RSD values-percentile standard deviation value for three measures

\section{Robustness}

HPLC based stability demonstrating approach robustness was weighed up by the analysis of standard TELM and AZEL solution (40 $\mu \mathrm{g} / \mathrm{ml}$ TELM and $8 \mu \mathrm{g} / \mathrm{ml}$ AZEL) by rendering some modest modifications in acetonitrile ratio (optimized $45 \%$ volume; altered $40 \%$ volume $\%$ and $50 \%$ volume), column rate of flow (optimized 1 $\mathrm{ml} / \mathrm{min}$; altered $0.9 \mathrm{ml} / \mathrm{min}$ and $1.1 \mathrm{ml} / \mathrm{min}$ ) $\mathrm{pH}$ (optimized 3.6 unit; altered 3.4 unit and 3.8 unit), column temperature (optimized $25^{\circ} \mathrm{C}$; altered $23^{\circ} \mathrm{C}$ and $27^{\circ} \mathrm{C}$ ) and wavelength (optimized $258 \mathrm{~nm}$; altered $256 \mathrm{~nm}$ and $260 \mathrm{~nm}$ ). Findings of robustness for TELM and AZEL are tabularized in table 4.

\section{TELM and AZEL stability testing}

The stability of TELM and AZEL in the presence of acid, base, light, heat, and oxidation was illustrated with the formulation solution.
The TELM and AZEL chromatogram after acid degradation testing showed four additional peaks at $1.908 \mathrm{~min}, 5.569 \mathrm{~min}, 5.835 \mathrm{~min}$ and $6.422 \mathrm{~min}$ except than TELM peak (2.751 $\mathrm{min})$ and AZEL peak (3.656 min). After acid degradation testing, $10.74 \%$ of TELM was degraded and $8.8 \%$ of AZEL was degraded. But for the TELM peak $(2.752 \mathrm{~min})$ and AZEL peak $(6.079 \mathrm{~min})$, the TELM and AZEL chromatograms after alkaline degradation testing revealed four additional peaks at $1.484 \mathrm{~min}, 1.892 \mathrm{~min}, 4.982 \mathrm{~min}$, and $6.079 \mathrm{~min}$. After acid degradation testing, $8.51 \%$ of TELM and $6.8 \%$ of AZEL were noticed to be degraded. The TELM and AZEL chromatogram after oxidation degradation testing showed three additional peaks at $1.192 \mathrm{~min}, 2.058 \mathrm{~min}$ and $5.061 \mathrm{~min}$ except for than TELM peak $(2.755 \mathrm{~min})$ and AZEL peak (3.661 min). After oxidation degradation testing, $5.34 \%$ of TELM was degraded and $4.29 \%$ of AZEL was degraded. After a photodegradation testing the chromatogram of TELM and AZEL had three extra peaks with a range of $1.261 \mathrm{~min}$, 
2.303 min, and 6.610 min other than TELM and AZEL peaks at 2.756 min and $3.660 \mathrm{~min}$, respectively. $7.59 \%$ of TELM was found degraded and $5.12 \%$ of AZEL was found degraded after photodegradation testing. The TELM and AZEL chromatogram after heat degradation testing showed four additional peaks at $1.183 \mathrm{~min}$, $1.789 \mathrm{~min}, 4.747 \mathrm{~min}$ and $6.100 \mathrm{~min}$ except for than TELM peak
(2.752 $\mathrm{min}$ ) and AZEL peak (3.657 min). After heat degradation testing, $11.42 \%$ of TELM was degraded and $9.82 \%$ of AZEL was degraded. The TELM and AZEL chromatograms after acid degradation testing, oxidation degradation testing, alkaline degradation testing, photodegradation testing, and heat degradation testing were represented in fig. 6.

Table 4: TELM and AZEL robustness measures

\begin{tabular}{|c|c|c|c|c|c|c|c|c|}
\hline \multirow[t]{2}{*}{ Condition } & \multicolumn{4}{|l|}{ TELM } & \multicolumn{4}{|l|}{ AZEL } \\
\hline & $\begin{array}{l}\text { Peak } \\
\text { response }\end{array}$ & Mean value & SD value & $\begin{array}{l}\text { RSD } \\
\text { value }\end{array}$ & $\begin{array}{l}\text { Peak } \\
\text { response }\end{array}$ & Mean value & SD value & $\begin{array}{l}\text { RSD } \\
\text { value }\end{array}$ \\
\hline \multicolumn{9}{|l|}{ Acetonitrile ratio } \\
\hline Optimized $45 \%$ vol & 2852318 & 2813478 & 37163 & 1.3 & 1589088 & 1561666 & 26804 & 1.8 \\
\hline Altered $40 \%$ vol. & 2809861 & & & & 1560384 & & & \\
\hline Altered 50\% vol. & 2778256 & & & & 1535526 & & & \\
\hline \multicolumn{9}{|c|}{ Column rate of flow } \\
\hline $\begin{array}{l}\text { Optimized } 1 \\
\mathrm{ml} / \mathrm{min}\end{array}$ & 2768902 & 2817027 & 52079 & 1.8 & 1539116 & 1562862 & 25078 & 1.7 \\
\hline Altered $0.9 \mathrm{ml} / \mathrm{min}$ & 2872318 & & & & 1589088 & & & \\
\hline $\begin{array}{l}1.1 \mathrm{ml} / \mathrm{min} \\
\mathbf{p H}\end{array}$ & 2809861 & & & & 1560384 & & & \\
\hline Optimized 3.6 unit & 2831726 & 2825374 & 13507 & 0.5 & 1571001 & 1570060 & 9242 & 0.6 \\
\hline Altered 3.4 unit & 2834535 & & & & 1578797 & & & \\
\hline Altered 3.8 unit & 2809861 & & & & 1560384 & & & \\
\hline \multicolumn{9}{|c|}{ Column temperature } \\
\hline Optimized $25^{\circ} \mathrm{C}$ & 2809861 & 2815219 & 49858 & 1.7 & 1560384 & 1562652 & 28329 & 1.9 \\
\hline Altered $23{ }^{\circ} \mathrm{C}$ & 2868256 & & & & 1535526 & & & \\
\hline Altered $27^{\circ} \mathrm{C}$ & 2867541 & & & & 1592048 & & & \\
\hline \multicolumn{9}{|l|}{ Wavelength } \\
\hline Optimized $258 \mathrm{~nm}$ & 2811832 & 2788037 & 39518 & 1.4 & 1608996 & 1588918 & 25385 & 1.7 \\
\hline Altered $256 \mathrm{~nm}$ & 2742420 & & & & 1597376 & & & \\
\hline Altered $260 \mathrm{~nm}$ & 2809861 & & & & 1560384 & & & \\
\hline
\end{tabular}

${ }^{*}$ mean of three measures; SD value-standard deviation value for three measures; RSD values-percentile standard deviation value for three measures
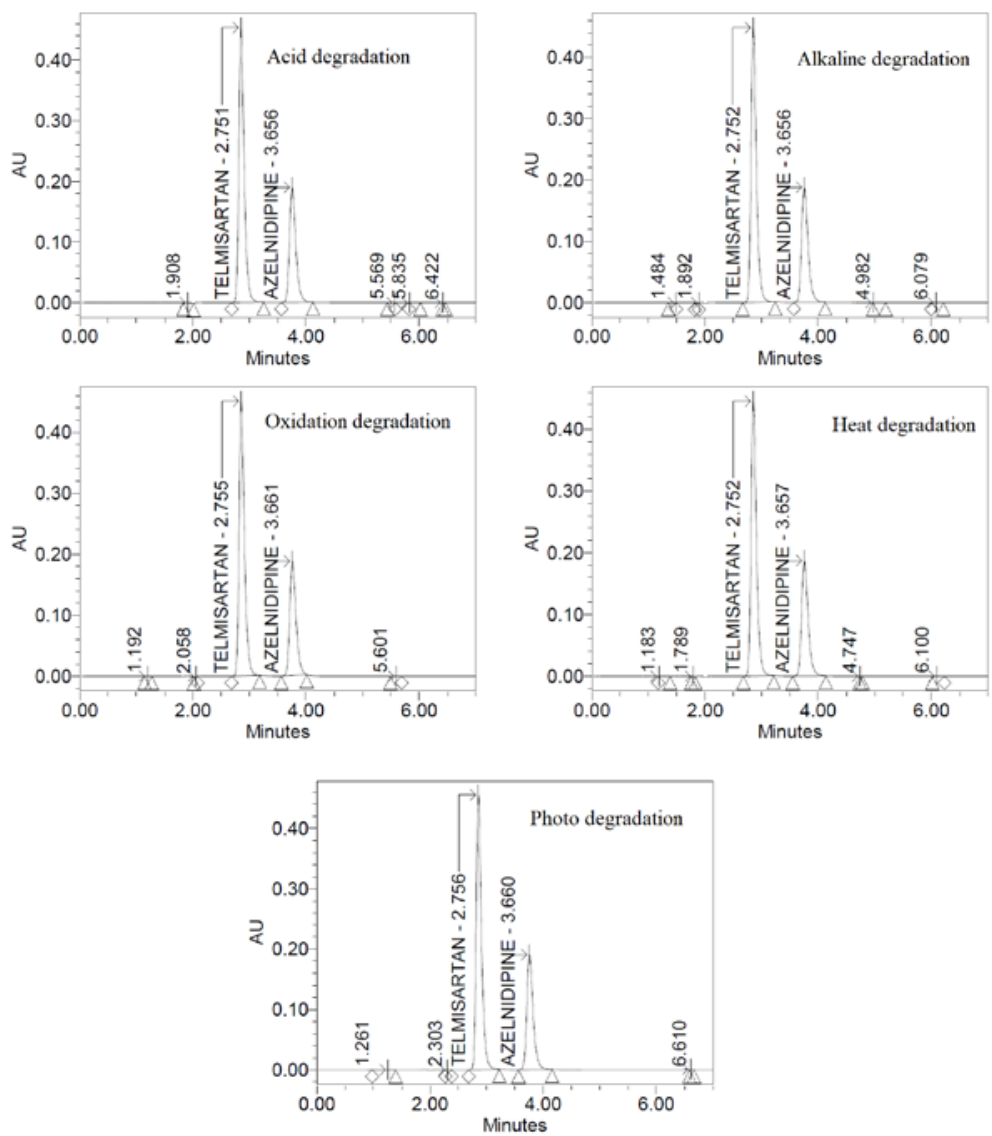

Fig. 6: Chromatogram of TELM and AZEL formulation solution after degradation 


\section{DISCUSSION}

The intention of the present work was to create HPLC-based stability demonstrating approach proficient in separating and determining TELM and AZEL well in the petite feasible analysis time with sensible precision, robust, selective and reliability. The column and solvents of the mobile phase were standardized till a best possible responses and peak structures for TELM and AZEL were achieved [19]. The columns that were examined at were: Kromasol C18, Develosil C18, Sunsil C18, Aligent C18 and Supelco C18. All examined stationary columns have identical dimensions $(5 \mu \mathrm{m} ; 4.6 \times 250 \mathrm{~mm})$. The solvent combinations that were examined at were: $0.1 \% \mathrm{H}_{3} \mathrm{PO}_{4}$-methanol; $0.1 \mathrm{M} \mathrm{NaH} \mathrm{NO}_{4-}$ methanol; and $0.1 \mathrm{M} \mathrm{Na}_{2} \mathrm{SO}_{4}$-acetonitrile. The temperature $\left(25{ }^{\circ} \mathrm{C}\right)$ atthe stationary column, column flow stream $(1 \mathrm{ml} / \mathrm{min})$, and injection analysis volume $(10 \mu \mathrm{l})$ were all held steady throughout the trial experimentations. Finally, the settings explained in section "Instrumentation and analysing conditions of TELM and AZEL combination" were opted to analyse the TELM and AZEL combination.

No peaks were spotted nearby to the RT of TELM and AZEL in diluent $\left(55 \%\right.$ volume $0.1 \mathrm{M} \mathrm{Na} \mathrm{SO}_{4}$ with $\mathrm{pH} 3.6$ and $45 \%$ volume acetonitrile), approximately the same RT of $(55 \%$ volume $0.1 \mathrm{M}$ $\mathrm{Na}_{2} \mathrm{SO}_{4}$ with pH 3.6 and $45 \%$ volume acetonitrile) in standard TELM and AZEL solution and formulation solution. Hence evidenced high selectivity of TELM and AZEL analysing method [20].

The TELM and AZEL's concentration was evidently linear for the proposed HPLC-based stability demonstrating approach in the possibility of $20-60 \mu \mathrm{g} / \mathrm{ml}$ and $4-12 \mu \mathrm{g} / \mathrm{ml}$, with strong linearity as correlation coefficient was 0.9996 and 0.9980 , respectively [21].

The low quantification and detection limits concentration values were considered reasonable, ample and sensitive for the TELM and AZEL analysing method [22].

The RSD assessments for the TELM and AZEL peak response were within $2 \%$, indicating that the HPLC-based stability demonstrating process was precise and repeatable for determining TELM and AZEL [23]. The recovery assessments for the TELM and AZEL assay within $100 \pm 2 \%$ recommended that HPLC based stability demonstrating approach was accurate and reliable for determining the TELM and AZEL [23].

Good recoveries for TELM (99.62\%-101.05\%) and AZEL (97.76\%$100.17 \%$ ) were achieved in standard addition methodology applied and proved no interfering from pharmaceutical excipients of TELMA-AZ tablets while analysing the TELM and AZEL [24].

The misplays in expressions of RSD for TELM and AZEL peak response after making some modest modifications in acetonitrile ratio $(1.3 \%$ for TELM and $1.8 \%$ for AZEL), column rate of flow $(1.8 \%$ for TELM and $1.7 \%$ for AZEL) $\mathrm{pH}(0.5 \%$ for TELM and $0.6 \%$ for AZEL), column temperature (1.7\% for TELM and $1.9 \%$ for AZEL) and wavelength $(1.4 \%$ for TELM and $1.7 \%$ for AZEL) within $2 \%$, indicating that the HPLC based stability demonstrating process was robust for determining the TELM and AZEL [25].

The choice of formulation production, storage, shipping, shelf life, packaging, and chemical stabilization of TELM and AZEL is directly influenced by stability testing [13-16, 26]. The TELM and AZEL were realised more stable under oxidation degradation testing conditions employed. The TELM and AZEL was realised more sensitive under heat degradation testing situations employed. The retention times of TELM, AZEL and degradation products got during acid degradation testing, oxidation degradation testing, alkaline degradation testing, photodegradation testing, and heat degradation testing conditions are completely different. Hence evidenced high stability demonstrating feature and specificity of TELM and AZEL analysing method.

\section{CONCLUSION}

A stability demonstrating methodology for analysing the TELM and AZEL combination in the tablets and bulk was elucidated in this report. This method found fit, based on the values obtained during validation experiments, for the quality regulatory analysis of TELM and AZEL combination in the quality declaration laboratories deprived of interference from pharmaceutical excipients of TELMA-AZ tablets and degradation products got in acid degradation testing, oxidation degradation testing, alkaline degradation testing, photodegradation testing, and heat degradation testing conditions employed.

\section{FUNDING}

Nil

\section{AUTHORS CONTRIBUTIONS}

All the authors have contributed equally.

\section{CONFLICTS OF INTERESTS}

Declared none

\section{REFERENCES}

1. Oparil S, Acelajado MC, Bakris GL, Berlowitz DR, Cifkova R, Dominiczak AF, et al. Hypertension. Nat Rev Dis Primers 2018;4:18014.

2. Mills KT, Stefanescu A, He J. The global epidemiology of hypertension. Nat Rev Nephrol 2020;16:223-37.

3. Chen B, Zhang Y, Luo J, Zhang W. Clinical use of azelnidipine in the treatment of hypertension in Chinese patients. Ther Clin Risk Manag 2015;11:309-18.

4. Zhao X, Wu F, Jia S, Qu P, Li H, Zhao X, et al. Azelnidipine and amlodipine: a comparison of their effects and safety in a randomized double-blinded clinical trial in Chinese essential hypertensive patients. Clin Exp Hypertens 2010;32:372-6.

5. Masaki W, Teruyuki H, Sadahisa O, Shinya S, Seiji T, Makoto U. Azelnidipine, a long-acting calcium channel blocker, could control hypertension without decreasing cerebral blood flow in post-ischemic stroke patients. A 123I-IMP SPECT follow-up study. Hypertens Res 2010;33:43-8.

6. Destro M, Cagnoni F, Dognini GP, Galimberti V, Taietti C, Cavalleri C, et al. Telmisartan: just an antihypertensive agent? A literature review. Expert Opin Pharmacother 2011;12:2719-35.

7. Suhas D, Deepak B, Kavita A. Review on pharmacovigilance study of telmisartan in hypertension pateints. Asian J Pharm Clin Res 2013;6:17-20.

8. Shahid UDD, Gangadharappa HV, Ashish NP. Formulation, development and characterization of drug delivery systems based on telmisartan encapsulated in silk fibroin nanosphere's. Int J Appl Pharm 2019;11:247-54.

9. Galzerano D, Capogrosso C, Di Michele S, Galzerano A, Paparello $\mathrm{P}$, Lama $\mathrm{D}$, et al. New standards in hypertension and cardiovascular risk management: focus on telmisartan. Vasc Health Risk Manag 2010;6:113-33.

10. Ayza MA, Zewdie KA, Tesfaye BA, Gebrekirstos ST, Berhe DF. Anti-diabetic effect of telmisartan through its partial PPAR $\gamma$ agonistic activity. Diabetes Metab Syndr Obes 2020;13:3627-35.

11. Balakumar P, Bishnoi HK, Mahadevan N. Telmisartan in the management of diabetic nephropathy: a contemporary view. Curr Diabetes Rev 2012;8:183-90.

12. Telmisartan+Azelnidipine. Available from: https://www.1mg.com/generics/telmisartan-azelnidipine509412 [Last accessed on 10 May 2021]

13. ICH Expert Working Group. International Conference on Harmonization (ICH) of technical requirements for the registration of pharmaceutical for human use stability testing of new drugs substance and products Q1A (R2); 2003.

14. Goparaju G, Kaushal G. Significance of stability-indicating LC methods in pharmaceuticals. Austin Chromatogr 2014;1:1-2.

15. Pandya CP, Rajput SJ. Development and validation of stabilityindicating method RP-HPLC method of acotiamide. Int J Pharm Pharm Sci 2018;10:1-8.

16. Rode DM, Rao NN. A review on development and validation of stability-indicating HPLC methods for the analysis of acidic drugs. Int J Curr Pharm Res 2019;11:22-33.

17. ICH Expert Working Group. Validation of Analytical Procedures: Text and Methodology Q2 (R1); 2005.

18. Ravichandran V, Shalini S, Sundaram KM, Rajak H. Validation of analytical methods-strategies and importance. Int J Pharm Pharm Sci 2010;2:18-22.

19. Azim Md Sabir, Mitra Moloy, Parminder S Bhasin. HPLC method development and validation: a review. Int Res J Pharm 2015;4:39-46. 
20. Marcello L, Dora M, Giuseppe C, Clinio L. Recent HPLC strategies to improve sensitivity and selectivity for the analysis of complex matrices. Instrum Sci Technol 2012;40:112-37.

21. Panchumarthy R, Navya ChN, Pravallika D, Sri DN. A review on step-by-step analytical method validation. IOSR J Pharm 2015;5:7-19.

22. Armbruster DA, Pry T. Limit of blank, limit of detection and limit of quantitation. Clin Biochem Rev 2008;29(Suppl 1):S49-S52.

23. Betz JM, Brown PN, Roman MC. Accuracy, precision, and reliability of chemical measurements in natural products research. Fitoterapia 2011;82:44-52.
24. Zenkevich IG, Klimova IO. Use of the standard addition method in quantitative chromatographic analysis.J Anal Chem 2006;61:967-72.

25. Sergio LCF, Adriana OC, Thaise da SB, Ariana MDSL, Laiana OBS, Walter NLS. Robustness evaluation in analytical methods optimized using experimental designs. Microchem J 2017;131:163-9.

26. Shah BP, Jain S, Prajapati KK, Mansuri NY. Stability Indicating HPLC method development: a review. Int J Pharm Res Sci 2012;3:2978-88. 